\title{
Internal ice - sheet variability as source for the multi-century and millennial-scale iceberg events during the Holocene? A model study
}

\author{
Marianne Bügelmayer-Blaschek ${ }^{1}$, Didier M. Roche ${ }^{1,2}$, Hans Renssen ${ }^{1}$, and John \\ T. Andrews ${ }^{3,4}$ \\ ${ }^{1}$ Earth and Climate Cluster, Faculty of Earth and Life Sciences, Vrije Universiteit Amsterdam, \\ Amsterdam, The Netherlands \\ ${ }^{2}$ Laboratoire des Sciences du Climat et de l'Environnement, LSCE/IPSL, CEA-CNRS-UVSQ, \\ Université Paris-Saclay, F-91191 Gif-sur-Yvette, \\ ${ }^{3}$ INSTAAR and Department of Geological Sciences, University of Colorado, Boulder, CO 80309, \\ USA \\ ${ }^{4}$ Department of Geological Sciences, University of Colorado, Boulder, CO 80309, USA \\ Correspondence to: M. Bügelmayer-Blaschek(m.bugelmayer@vu.nl)
}

\begin{abstract}
The climate of the Holocene, the current interglacial covering the past 11,700 years, has been relatively stable compared to previous periods. Nevertheless, repeating occurrence of rapid natural climate changes that challenged human society are seen in proxy reconstructions. Ocean sediment cores for example display prominent peaks of enhanced ice rafted debris (IRD) during the Holocene with a multi-decadal to millennial scale periodicity. Different mechanisms were proposed that caused these enhanced IRD events, for example variations in the incoming total solar irradiance (TSI), volcanic eruptions and the combination of internal climate variability and external forcings.
\end{abstract} We investigate the probable mechanisms causing the occurrence of IRD-events over the past 6,000 years using a fully coupled climate - ice-sheet - iceberg ( $i$ LOVECLIM) model. We performed 18 experiments that differ in the applied forcings (TSI, volcanic) and the initial atmospheric conditions. To explore internal ice sheet variability one further experiment was done with fixed climate conditions. All the model runs displayed prominent peaks of enhanced iceberg melt flux (IMF), independent of the chosen experimental set-up. The spectral analysis of the experiments with the ice-sheet - climate model coupled displays significant peaks at 2,000, 1,000 years in all the experiments and at 500 years in most runs. The experiment with fixed climate conditions displays one significant peak of about 1,500 years related to internal ice sheet variability. This frequency is modulated to 2,000 and 1,000 years in all the experiments with a coupled climate - ice sheet due to interactions between the climate components. We further investigate the impact of minimum TSI events on the timing and occurrence of enhanced IMF. In the experimental set-up that was forced with idealized sinusoidal TSI variations $\left( \pm 4 \mathrm{~W} \mathrm{~m}^{-2}\right)$, we find a significant occurrence of an increased iceberg melt flux about 60 years after the minimum TSI value. Yet, we also see a significant time lag of 80 years between reconstructed TSI minima and the simulated enhanced iceberg melt flux in some of the experiments without TSI forcing. The fact that also model runs that are not forced with TSI variations display an 80 year time lag indicates that the relationship between TSI and IMF is due to internal dynamics of the coupled system. 
From our experiments we conclude that internal ice sheet variability seems to be the source of the multi-century and millennial-scale iceberg events during the Holocene.

\section{Introduction}

The climate of the past 11,700 years, the Holocene, did not experience strong changes compared to previous periods. This provided the possibility for humans to establish our current society (Wanner et al. 2011) that is now facing unprecedented challenges due to a fast changing climate. But even during the relatively stable Holocene, there have been rapid natural climate changes (e.g. Denton and Karlén, 1973; Wanner et al., 2008, 2011, 2015, Walker et al., 2012) that coincide with disruptions in human society, illustrating the impact of the prevailing conditions and changes therein on humans (Mayewski et al. 2004). Evidence of changing climate conditions, such as temperature and precipitation, during the past is found in proxy reconstruction made from tree rings, ice cores as well as ocean sediments (e.g. Bond et al., 1997, 1999, 2001; Bianchi and McCave, 1999; Andersen et al. 2004).

In ocean sediment cores the occurrence of Ice Rafted Debris (IRD) indicate that icebergs floated over a specific site and melting in the deposition of sediment. The increase in IRD of a certain size fraction (Andrews et al., 2000) in a sediment core is used as a proxy of enhanced iceberg melt flux. Moreover, by analyzing the mineralogy of the IRD the most probable calving location can be identified (Andrews et al. 2014). The quantity of IRD found in one sediment core depends first on the amount of icebergs calved from the ice sheet, second on the prevailing ocean and wind currents that transport the bergs and thirdly on the melting history (Ruddiman, 1977). Cores taken south and east of Greenland display periods of enhanced IRD during the last glacial as well as the Holocene with a multi-century to millennial scale periodicity (e.g. Andrews et al., 1997; Andrews, 2009; Andrews et al., 2014, Jennings et al., 2002, Bendle and Rosell-Melé, 2007). Moreover, Bond et al. (1997 2001) presented IRD records from cores located in the North Atlantic, which show periodicities of

1,500 years. However, there is some debate whether these records display changes in IRD due to changed iceberg transport or rather reflect for example pulses in overflow water Andrews et al. 2014). In addition, Obrochta et al. (2012) questioned if the 1,500 year cycle reported by Bond et al. (1997, 2001) may be a transient signal instead of a physically caused cycle.

Further evidence of colder and drier conditions as well as periods of advanced glaciers has been found in global proxy data for the Northern and Southern Hemispheres (Mayewski et al. 2004 Wanner et al. 2008, 2011). These changes are thought to be driven by a globally active mechanism, or a chain of mechanisms that affect both hemispheres synchronously and coincide with enhanced IRD fluxes in the Northern Hemisphere (Wanner et al., 2011).

A possible mechanism was proposed by Bond et al. (2001), who related periods of increased IRD flux, based on hematite-stained grains recorded in four ocean cores around Greenland, to periods of 
decreased total solar irradiance (TSI), using the production rate of cosmogenic nuclides Carbon-14 and Beryllium-10 as proxies of TSI. They found a significant correlation between the external TSI forcing and the increased IRD flux recorded in ocean sediment cores close to the Greenland ice sheet (GrIS) and in the North Atlantic.

Due to feedback mechanisms within the climate system, a weak external forcing such as variations in the incoming total solar irradiance can have substantial climatic impact. Renssen et al. (2006) conducted a study using a coupled ocean-atmosphere-vegetation model and revealed that the probability of a colder ocean state increases with decreasing TSI. Therefore, they concluded that the ocean further enhances the weak TSI forcing. Moreover, modeling studies addressing the dynamical effects of TSI variations on stratospheric ozone indicated that negative TSI anomalies also cause colder stratospheric temperatures due to decreased stratospheric ozone formation (Haigh 1994, 1996). The colder stratospheric temperatures can propagate downward and thereby even change the atmospheric circulation (Haigh, 1994; Shindell et al., 1999, 2001).

Anotherpossible mechanism for the occurrence of the Holocene IRD events are strong volcanic eruptions. Large-scale eruptions can cause an average global cooling of $0.1-0.2^{\circ} \mathrm{C}$ because they decrease the incoming solar radiation at the surface (Robock, 2000). The Northern Hemisphere (NH) is more sensitive to the related radiative cooling due to its larger land surface. During winter, stronger mid-latitude westerlies occur to counteract the enhanced meridional heat gradient that favor positive North-Atlantic-Oscillation (NAO) and Arctic-Oscillation (AO) indices. Therefore, a related warming over the western NH and a cooling over the arctic region and eastern NH is observed (Shindell et al. 1999. 2004). Moreover, (Miller et al., 2012) argued that the cooling effect of volcanic eruptions can be maintained for years after the eruptions due to sea-ice - ocean feedbacks.

Recently, (Jungclaus et al., 2010) concluded that multi-centennial climate variation like the Medieval Warm Period might represent internal variability of the climate system rather than a response to TSI variations. The authors used a comprehensive Earth System model to investigate the climate variability over the past millennium using TSI and volcanic reconstructions as forcing fields. Jungclaus et al. (2010) find a clear cooling impact of volcanic eruptions on the global temperatures, but the climate response to variations in TSI is within the same range as internal climate variability. Also Mignot et al. (2011) displayed a stronger model response to volcanic eruptions than to changes in the incoming solar radiation. Moreover, Khider et al. (2014) argue that the millennial scale variations in sea surface temperatures seen in a core from the western tropical Pacific are due to variations in the deep ocean circulation, independent of external forcings. The authors came to this conclusion by investigating planktonic and benthic foraminifera found in the same core from the western tropical Pacific. The planktonic record displays millennial-scale SST oscillations whereas the benthic record shows millennial-scale changes of Upper Circumpolar Deep Water.

Other studies proposed that there might not be one sole cause for the various cold events and periods of increased IRD, but rather a combination of different mechanisms, such as freshwater 
pulses, variations in total solar irradiance as well as the combination of different factors for each event (Mayewski et al., 2004, Wanner et al., 2008, 2011, 2015).

Climate models are valuable tools to investigate the impact of various forcings, such as TSI or volcanic eruptions on climate as well as to analyze the interactions between the different climate components. Only recently, the Past4Future project (http://www.past4future.eu) supported the compilation of TSI and volcanic emission reconstructions covering the whole Holocene. Additionally, the PMIP project (https://pmip.lsce.ipsl.fr/) compiled the greenhouse gas (GHG) forcing, thus providing the possibility to perform transient experiments over the past thousands of years with all the external forcings included.

Therefore, we use the earth system model of intermediate complexity iLOVECLIM, a fully coupled climate - cryosphere model (Roche et al., 2014, Bügelmayer et al., 2015) that dynamically computes iceberg calving and transport, to perform long - term simulations to address the following questions:

(1) Can we reproduce the periods of increased iceberg flux observed in ocean sediment cores close to Greenland and in the North Atlantic? (2) Can we determine the mechanism of these increased iceberg events? To answer these questions, we concentrated on the last 6,000 years and performed 1 experiment where we prescribed periodic variations in TSI and volcanic forcing, 15 ensemble experiments that varied in the strength of the TSI forcing prescribed, as well as 3 additional experiments without any volcanic forcing.

In the presented paper, we will first explain in detail the climate model and forcings used as well as the experiments performed, continue with our results and finish with the discussion and conclusions.

\section{Methods}

\subsection{Climate Model $i$ LOVECLIM}

The iLOVECLIM climate model includes the atmospheric model ECBilt (Opsteegh et al., 1998), a quasi-geostrophic, spectral model calculated on a horizontal T21 truncation ( $5.6^{\circ}$ in longitude/latitude) and three vertical pressure levels $(800,500,200 \mathrm{hPa})$. The atmospheric variables, e.g. precipitation and temperature, are computed every four hours. Precipitation is only incorporated in the lowermost level depending on the available humidity. The vegetation model VECODE (Brovkin et al., 1997) is computed on the same grid as ECBilt, but fractional use of one grid cell is allowed due to the small spatial changes in vegetation. The vegetation (tree, grass or bare soil) depends on the temperature and precipitation as provided by ECBilt. Further, the ocean model CLIO consists of a dynamic thermodynamic sea-ice model (Fichefet and Maqueda, 1997, 1999) coupled to a 3D ocean general circulation model (Deleersnijder and Campin, 1995; Deleersnijder et al., 1997; Campin and Goosse 1999). The oceanic variables, sea temperature and salinity, are computed daily and on a $3 \times 3^{\circ}$ latitude longitude grid. CLIO consists of 20 unevenly spaced vertical layers. The computation of the albedo 
of sea ice depends on its state (frozen or melting) and the thickness of the snow and ice cover (Goosse et al. 2010). The free surface of the ocean model allows the use of real freshwater fluxes.

The ice-sheet model GRISLI (Ritz et al., 1997, 2001) is a three-dimensional thermomechanical ice sheet model first developed for Antarctica and then further expanded to include the Northern Hemisphere (Peyaud et al. 2007). In this study we concentrate on the Greenland ice sheet, thus only the Northern Hemisphere grid is used and the Antarctic ice sheet is prescribed and fixed to present day values. The resolution of GRISLI is $40 \times 40 \mathrm{~km}$ on a Lambert azimuthal grid. It predicts the changes in geometry (thickness and extension) of the ice sheet according to the surface mass balance (accumulation minus ablation) and ice flow. The surface mass balance of GRISLI depends on the monthly temperatures and the yearly snowfall as computed in ECBilt (Roche et al., 2014). Three different glaciological conditions are taken into account, namely inland ice, ice streams and ice shelves. The inland ice is computed using the 0-order shallow ice approximation (Hutter, 1983, Morland, 1984) whereas the calculation of fast flowing ice streams and ice shelves is based on the shallow shelf approximation (MacAyeal, 1989). Calving occurs whenever the ice sheet thickness at the border of the ice sheet is below $150 \mathrm{~m}$ and there is not enough ice coming from the points upstream to maintain the height above the threshold. The total amount of calved ice is accumulated over one GRISLI model year and then given to the iceberg model and can thus add up to more than $150 \mathrm{~m}$. The surface runoff and basal melt are computed at the end of one model year by taking the difference between the ice sheet thickness at the beginning and at the end of the year and considering the mass lost due to calving. After one GRISLI model year, the runoff (surface and basal melt) is incorporated in the land routing scheme of ECBilt and the calving flux is given to the iceberg model (Bügelmayer et al., 2015).

In the iceberg model (Bigg et al., 1996, 1997, Gladstone et al., 2001, Jongma et al., 2009, 2013, Wiersma and Jongma, 2010) the yearly calving flux is used to daily generate icebergs according to a monthly distribution (Reid, 2005). Every day icebergs of 10 size classes, as defined by Bigg et al. (1996) based on present day Greenland observations (Dowdeswell et al., 1992), are produced if enough ice mass is available. The icebergs are then moved according to the prevailing oceanic (sea ice drag, water drag and horizontal pressure gradient) and atmospheric (air drag and wave radiation force) conditions. If the icebergs melt, their length to height ratio changes and they are allowed to roll over. The latent heat needed to melt the icebergs is taken from the surrounding ocean and the melt water is applied to the ocean surface (Bügelmayer et al., 2015). In the present model, splitting up of icebergs, refreezing of melt water and the sediment load transported by icebergs are not included.

\subsection{Forcing Fields}

We used two TSI reconstructions, which differ in amplitude, but not in the timing of the minima (maxima), to investigate their impact on the modeled Greenland calving flux and icebergs. First, we applied the TSI variations as presented by Steinhilber et al. (2009) who obtained a time series cover- 
a) Variations in Total Solar Irradiance (TS)

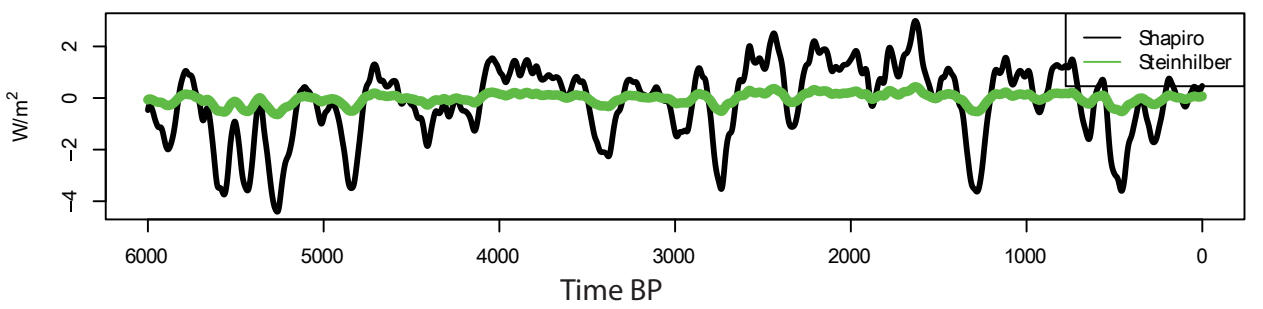

b) Volcanic Forcing

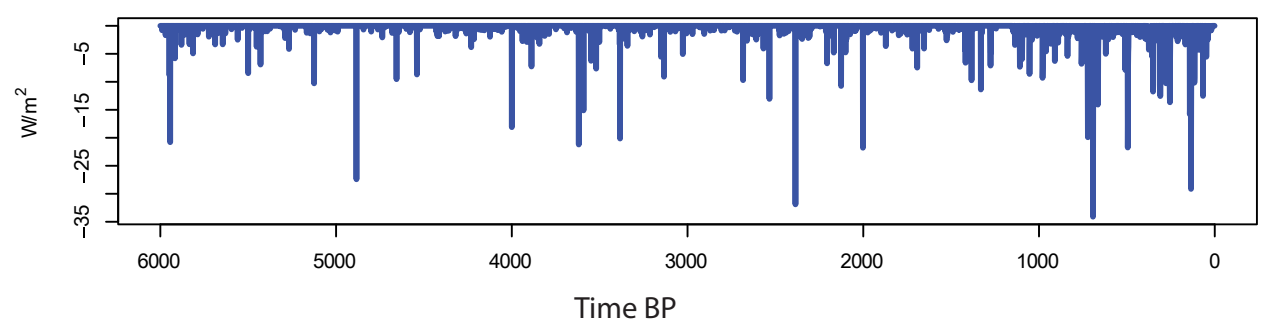

c) Greenhouse Gas Forcing

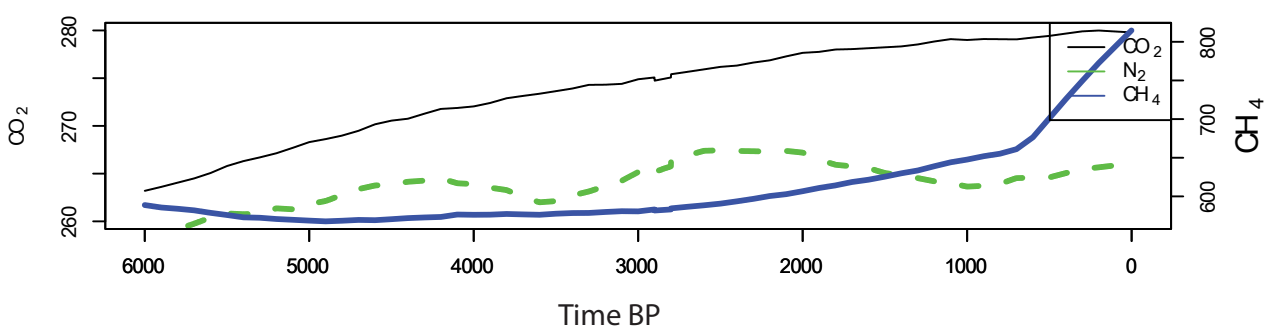

Figure 1. (a) 100 year running mean of variations in Total Solar Irradiance (TSI) as reconstructed by Steinhilber et al. (2009), green line and Shapiro et al. (2011), black line; (b) Volcanic forcing; (c) $\mathrm{CO}_{2}, \mathrm{~N}_{2} \mathrm{O}$ and $\mathrm{CH}_{4}$ (=greenhouse gas (GHG) forcing) 
ing the past 9300 years (Figure 19, green line). In their study, they used the cosmogenic radionuclide $10 \mathrm{Be}$ obtained from ice cores to compute the open solar magnetic field that is needed to reconstruct TSI. They find that the TSI varied by $\pm 1 \mathrm{~W} \mathrm{~m}^{-2}$ over the considered time period, thus the mean value of $1364 \mathrm{~W} \mathrm{~m}^{-2}$ was globally increased and decreased by up to $1 \mathrm{~W} \mathrm{~m}^{-2}$, respectively.

Second, we used the TSI reconstruction published by Shapiro et al.(2011)(Figure 1a, black line), who use the same cosmogenic radionuclide 10Be proxy, but compute the solar irradiance by taking into account the active and quiet regions of the sun based on observations of the last years. To reconstruct TSI variations over the past, the ratio between active and quiet sun is scaled with proxies for solar activity. Due to their definition of the quiet sun, their amplitude varies by up to $\pm 5 \mathrm{~W} \mathrm{~m}^{-2}$ over the past 7000 years. Thus, using the reconstruction published by Shapiro et al. (2011), we alter the mean value of $1364 \mathrm{~W} \mathrm{~m}^{-2}$ globally by up to $5 \mathrm{~W} \mathrm{~m}^{-2}$.

We further prescribed the radiative effect of volcanic eruptions following the reconstructions of Crowley et al. (2008) and Bo Vinther (personal communication, Figure 1p). Large volcanic eruptions pump sulfates into the stratosphere thereby decreasing the incoming solar radiation. In $i$ LOVECLIM volcanic eruptions are represented by decreased incoming solar radiation, which is latitudinally dependent according to the location of the volcano. This is in contrast to the globally uniform TSI variations. If both forcings (TSI and volcanic eruptions) are applied the mean value of incoming radiation is altered globally according to variations in TSI and also latitudinally dependent according to volcanic eruptions.

Reconstructed $\mathrm{CO}_{2}, \mathrm{~N}_{2} \mathrm{O}$ and Methane fluxes (greenhouse gases, GHG) are taken from the PMIP project (Figure 1). Moreover, the orbital forcing is computed following Berger (1978) inducing a long-term cooling trend over the past 6000 years caused by the decreasing summer insolation over the Northern Hemisphere.

\subsection{Experimental set-up}

Starting from an equilibrated pre-industrial ice sheet (Bügelmayer et al. 2015), we performed a 3,000 year spin-up period where we applied constant $6 \mathrm{kyr}$ BP (6,000 years Before Present (BP)) orbital and GHG values. The pre-industrial ice sheet is a valid initial condition because the Northern Hemisphere ice sheet configuration at 6kyr BP was similar to present day (Vinther et al. 2009) and the ice sheet margin was near or behind the present day margin (Ten Brink and Weidick, 1974 , Funder et al. 2011).

We then conducted three sets of experiments that differ in the applied TSI forcings. First, 5 ensemble runs of the control simulation without any TSI variations, but with volcanic eruptions (CTRLv) were performed Table 1]. Second, we ran 5 experiments where we applied the TSI variations reconstructed by Steinhilber et al. (2009) (LOWv) and third, we computed 5 runs altered by the TSI variations as defined by Shapiro et al. (2011) (HIGHv, Table 1). The ensemble runs were started from the same ice-sheet and ocean state, but with different atmospheric conditions, which were obtained 
205 by performing additional 1000 model years after the spin up period and saving the atmospheric conditions every 200 years.

We further performed three experiments without including the cooling effect of volcanic eruptions, but with the same TSI forcing as in the ensemble experiments (CTRL, LOW and HIGH, Table 1). This was done in order to investigate the impact of the radiative forcing related to volcanic eruptions 210 on the Greenland ice discharge and the icebergs' distribution.

In addition, we tested the impact of an idealized periodic TSI forcing (sinTSI, Table 1). We conducted one run where we applied sinusoidal variations of up to $\pm 4 \mathrm{~W} \mathrm{~m}^{-2}$ and a periodicity of 400 years. Finally, an experiment was performed where the ice sheet model GRISLI was fed once with a 50 year model climatology and then run for 5000 years without interacting with ECBilt or CLIO to 215 test internal ice sheet variability (fixCLIM, Table 1. 
Table 1. Performed experiments

\begin{tabular}{|c|c|c|c|c|c|c|c|c|}
\hline & & & $\begin{array}{l}\text { TSI Stein- } \\
\text { hilber et al., } \\
2009 \text {, }\end{array}$ & $\begin{array}{l}\text { TSI } \\
\text { (Shapiro } \\
\text { et al., 2011) }\end{array}$ & $\begin{array}{l}400 \text { year } \\
\text { Periodic } \\
\text { TSI forcing }\end{array}$ & $\begin{array}{l}\text { Volcanic } \\
\text { Forcing }\end{array}$ & $\begin{array}{l}\text { Initial } \\
\text { atmosph. } \\
\text { conditions }\end{array}$ & \\
\hline$S$ & 1 & CTRLv-1 & & & & $X$ & - & \\
\hline $\mathrm{T}$ & 2 & CTRLv-2 & & & & $X$ & 200 & \\
\hline A & 3 & CTRLv-3 & & & & $\mathrm{X}$ & 400 & \\
\hline $\mathrm{N}$ & 4 & CTRLv-4 & & & & $X$ & 600 & \\
\hline D & 5 & CTRLv-5 & & & & $\mathrm{X}$ & 800 & \\
\hline A & 6 & LOWv-1 & $X$ & & & $X$ & - & \\
\hline $\mathrm{R}$ & 7 & LOWv-2 & $X$ & & & $X$ & 200 & \\
\hline D & 8 & LOWv-3 & $X$ & & & $X$ & 400 & \\
\hline & 9 & LOWv-4 & $X$ & & & $X$ & 600 & \\
\hline$S$ & 10 & LOWv-5 & $\mathrm{X}$ & & & $\mathrm{X}$ & 800 & \\
\hline $\mathrm{E}$ & 11 & HIGHv-1 & & $X$ & & $X$ & - & \\
\hline $\mathrm{T}$ & 12 & HIGHv-2 & & $X$ & & $X$ & 200 & \\
\hline- & 13 & HIGHv-3 & & $X$ & & $X$ & 400 & \\
\hline U & 14 & HIGHv-4 & & $X$ & & $X$ & 600 & \\
\hline $\mathrm{P}$ & 15 & HIGHv-5 & & $X$ & & $X$ & 800 & \\
\hline $\mathrm{N}$ & 16 & CTRL & & & & & - & \\
\hline o & 17 & LOW & $X$ & & & & - & \\
\hline \multirow[t]{3}{*}{ V } & 18 & $\mathrm{HIGH}$ & & $X$ & & & - & \\
\hline & 19 & $\operatorname{sinTSI}$ & & & $X$ & $X$ & - & \\
\hline & 20 & fixCLIM & & & & $X$ & - & $\begin{array}{l}50 \mathrm{yr} \text { mean } \\
\text { climate }\end{array}$ \\
\hline
\end{tabular}



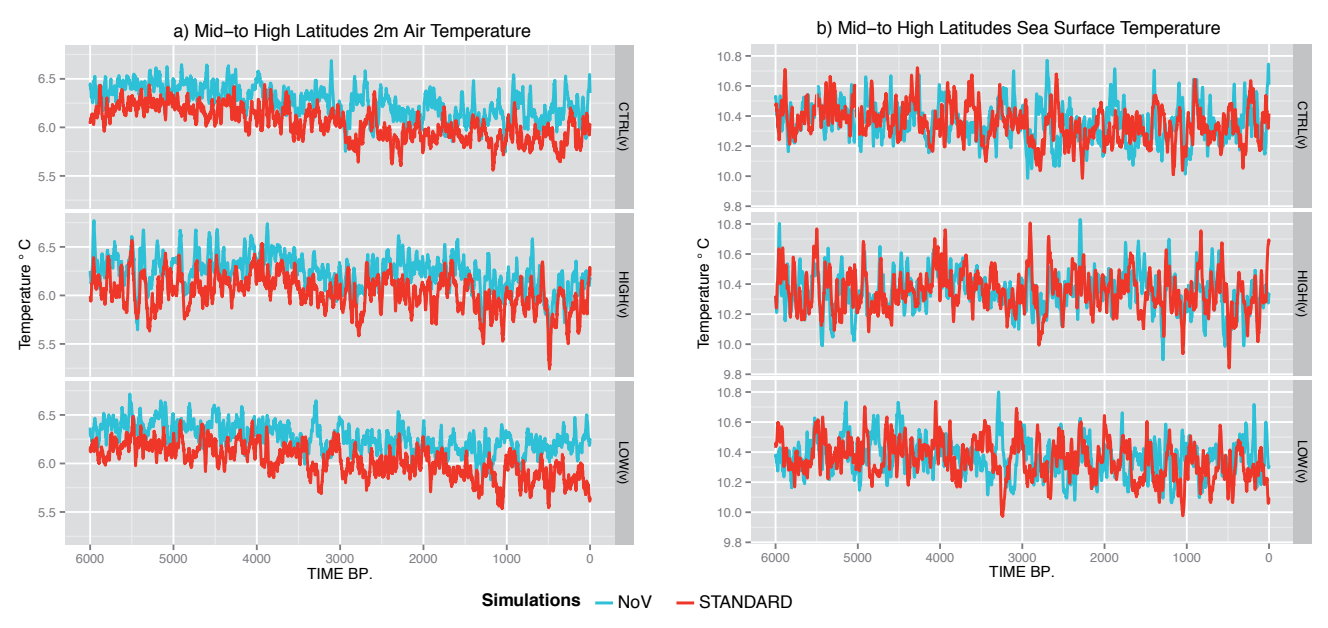

Figure 2. Mid- to High Latitude Area Mean $\left(80^{\circ} \mathrm{W}-15^{\circ} \mathrm{E}, 40^{\circ}-90^{\circ} \mathrm{N}\right)$ of (a) $2 \mathrm{~m}$ Air Temperatures; (b) Sea Surface Temperature. The red line corresponds to CTRLv/HIGHv/LOWv-1 and the blue line to CTRL/HIGH/LOW; only the first ensemble member is shown because they share the same starting conditions as the NoV runs.

\section{Results}

Before explicitly answering the research questions posed in the introduction, we present the modeled climate over the past 6kyr to evaluate the model performance.

\subsection{Modeled Holocene climate}

The simulated Holocene climate is characterized by the long-term, orbitally induced insolation changes with a decrease in summer insolation in the NH. This causes an overall cooling trend in both air (TAIR) and sea surface temperatures (SST) in all the experiments performed (Figure 2a,b). Superimposed on the long-term trend are short-term variations in SST and TAIR that represent internal variability as well as the effect of the applied forcings. Especially in HIGH(v) at $5.5-5 \mathrm{kyrBP}$ the variations in TSI have a strong response. The effect of the volcanic forcing is for example visible in the comparison of CTRLv and CTRL at 2.3 to $2 \mathrm{kyrBP}$, where CTRLv displays decreasing air temperatures whereas TAIR in CTRL is at first not changing and then increasing. In the HIGHv and LOWv set-ups the negative volcanic effect is partly counteracted by positive TSI values, thereby decreasing the difference between the experiments. It is interesting to notice that the TAIR in the standard set-up is about $0.2^{\circ} \mathrm{C}$ lower than in the experiments without volcanic forcing, clearly displaying the response of the model to the decreased radiative forcing caused by volcanic eruptions. 


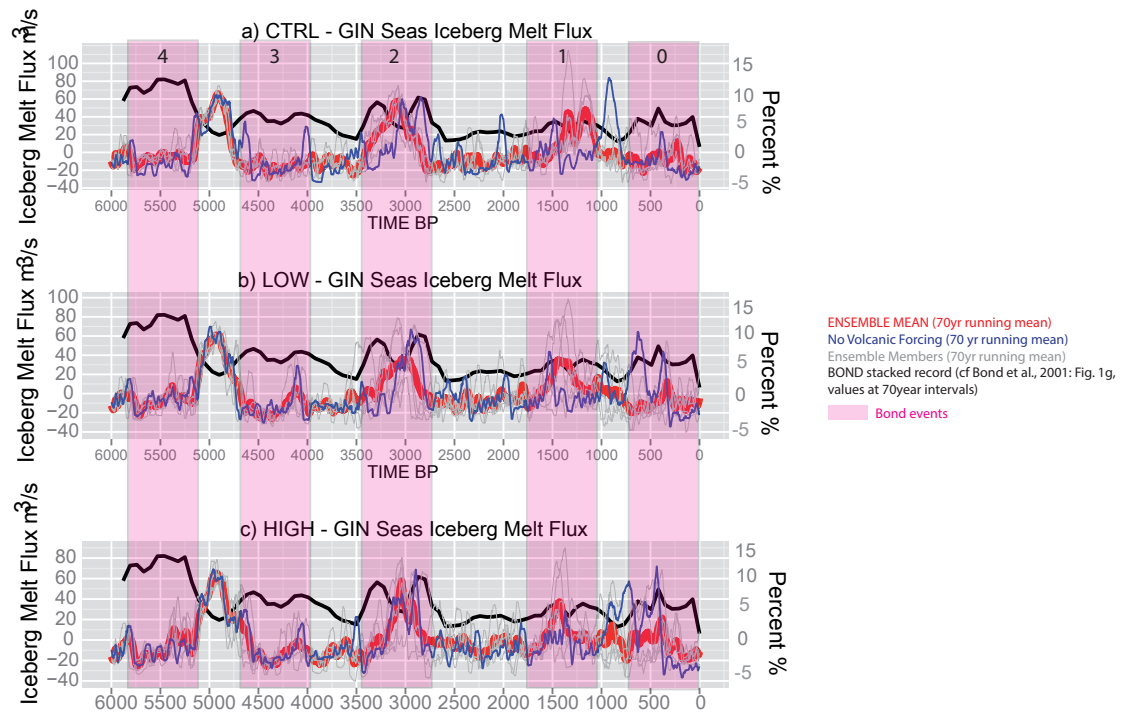

Figure 3. Bold black line is the stacked proxy data (\%) as presented by Bond et al., 2001 (cf. Fig. $2 \mathrm{~g}$, online available see caption Figure 4; the stacked proxy data can be interpreted as an ?ensemble mean? of the 5 sediment cores used by Bond et al. (2001). The resolution of the proxy data is 70 years, therefore, we computed the 70 year running mean of the modeled iceberg melt flux, taken over the area of $45^{\circ} \mathrm{W}-15^{\circ} \mathrm{E}, 50^{\circ}-85^{\circ} \mathrm{N}$ to capture the core locations. The thick red line is the ensemble mean of the 5 ensemble members, the thin grey lines correspond to the individual members, the blue line corresponds to the experiment performed without incorporating volcanic eruptions. The pink bars are the Bond events number 4 to 0; (a) CTRL; (b) LOW; (c) HIGH

\subsection{The simulated iceberg melt flux}

In the following section we present the iceberg melt flux instead of the Greenland calving flux because it depends on both the ice discharge and the transport of the icebergs, as does the IRD data from the ocean sediment cores. We thus expect the IMF to be more comparable to IRD than the calving flux and will therefore compare the IMF to the IRD records, since we do not explicitly simulate the (unknown) sediment load of icebergs. Moreover, note that the modeled IMF and ice discharge from the GrIS strongly correlate ( $r>0.96)$.

\subsubsection{Mechanisms of enhanced iceberg discharge}

The computed iceberg melt fluxes (IMF) of all the actively coupled (climate - ice-sheet) experiments display up to 5 distinct phases of increased values during the last 6000 years (Figure 3. The ensemble mean of CTRLv/LOWv/HIGHv displays three major events that peak at around 5000, 3000 and 1250 years BP that are also prominent in the NoV set-up. The bold black line represents the ocean stacked record of four cores published by Bond et al. (2001) (cf. their Figure 2) that is plotted here 


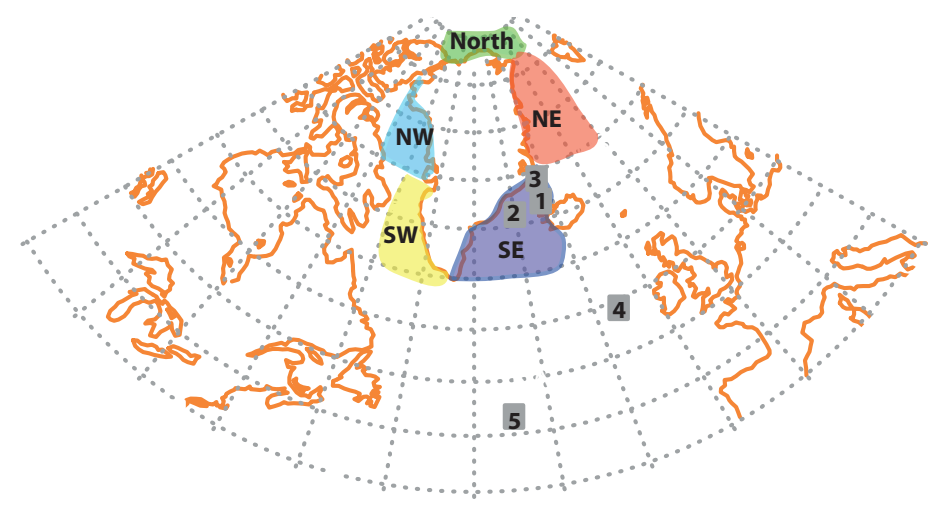

Figure 4. map showing core locations and areas used in figures 5 and 7: North $=$ North Greenland: Lon: $70^{\circ} \mathrm{W}$ - $0^{\circ} \mathrm{E}$, Lat: $80^{\circ}-85^{\circ} \mathrm{N}$; NE $=$ North-East Greenland: Lon: $25^{\circ} \mathrm{W}-0^{\circ} \mathrm{E}$, Lat: $70^{\circ}-80^{\circ} \mathrm{N}$; NW $=$ NorthWest Greenland: Lon: $70^{\circ}-50^{\circ} \mathrm{W}$, Lat: $70^{\circ}-80^{\circ} \mathrm{N}$; $\mathrm{SE}=$ South-East Greenland: Lon: $45^{\circ}-20^{\circ} \mathrm{W}$, Lat: $60^{\circ}-$ $70^{\circ} \mathrm{N}$; SW $=$ South-West Greenland: Lon: $60^{\circ}-45^{\circ} \mathrm{W}$, Lat: $60^{\circ}-70^{\circ} \mathrm{N}$; Numbers correspond to ocean cores: 1$)$ JR51GC35; 2) MD99-2269; 3) JM96-1205 at the same site as MD99-2317; 4) VM29-191; 5) KN158-4 GGC22

for reference. Moreover, the detrended magnitude of released freshwater (up to $100 \mathrm{~m}^{3} \mathrm{~s}^{-1}$ Figure 3 . is similar in all the experiments. The ensemble mean averages over the five ensemble members, thus smooths the internal variability and displays lower maximum values than the single runs. To summarize, we don't detect a clear impact of the TSI or the volcanic forcing on the iceberg melt fluxes. Instead, Figure 3 displays a coincidence in the timing of the major events of enhanced IMF within the different experiments.

The results of the spectral analysis display significant frequencies at 2,000 and 1,000 years in almost all the experiments (Figure $5 \mathrm{a}, \mathrm{b}, \mathrm{c}, \mathrm{d})$, independent of the initial atmospheric conditions. This analysis was done in order to gain better insight on the effect of the forcings on the occurrence of enhanced IMF events. We used the PAST software (Hammer et al., 2001) to analyze the model data as well as ocean sediment cores and the model results were averaged over 70 years to fit to the proxy resolution of Bond et al. (2001). The PAST software includes the REDFIT spectral analysis based on the REDFIT procedure of Schulz and Mudelsee (2002). It is a more advanced version of the Lomb periodogram and includes different windowing techniques as well as an AR(1) red noise model.

In addition to the 2,000 and 1,000 years peak, the HIGHv ensemble members, NoV and sinTSI experiments display a further peak at 500 years, which is also seen in most of the CTRLv and some LOWv members Figure 5. Since the 2,000 year peak can only occur 3 times within 6,000 years, its robustness was further tested and confirmed by cutting one peak of the IMF time series and repeating it 5 times (Thom Laepple, personal communication).The applied TSI forcing (Figure 5) enhances the shorter frequencies at around 300 to 100 years, especially in the HIGHv runs, but also in the LOWv set-up (Figure 5,c). The accordance between the experiments is striking because they differ significantly in iceberg melt flux, ocean- and air temperature (Table 2]. It is important to notice that 
a) CTRLv exp. - Welch Window Function

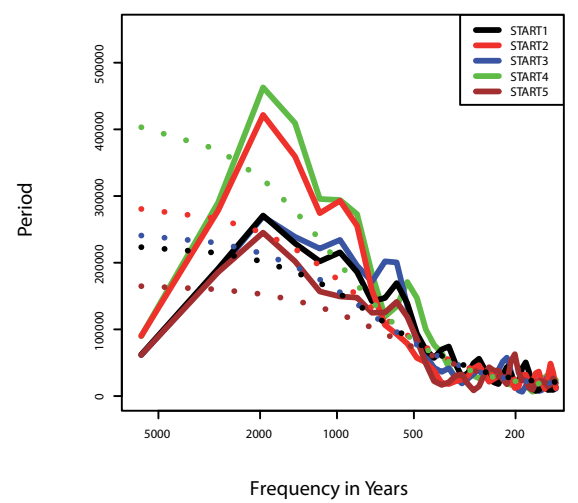

c) HIGHv exp. - Welch Window Function

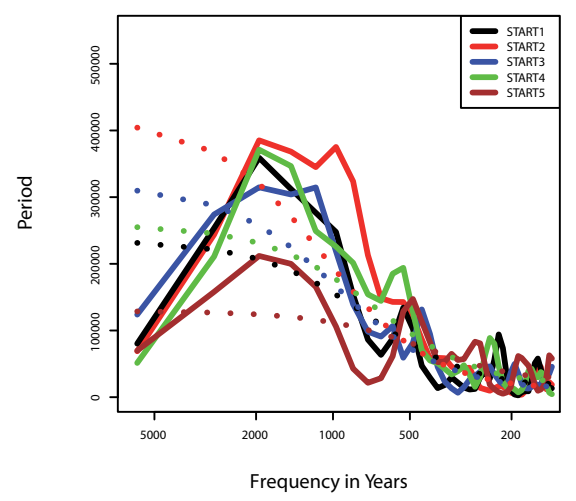

e) IRD4 - Welch Window Function

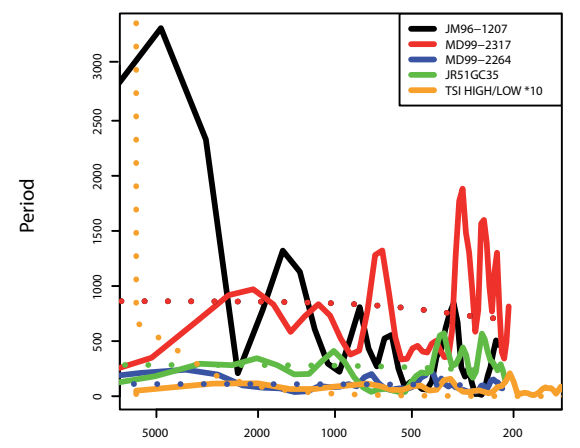

b) LOWv exp. - Welch Window Function

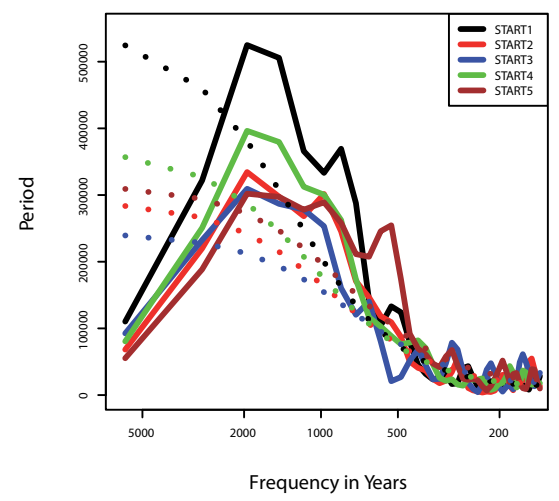

d) NoV \& sinTSI exp. - Welch Window Function

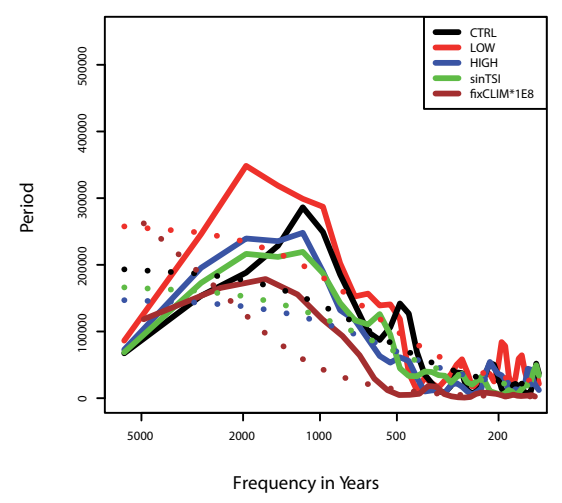

f) Bond IRD - Welch Window Function

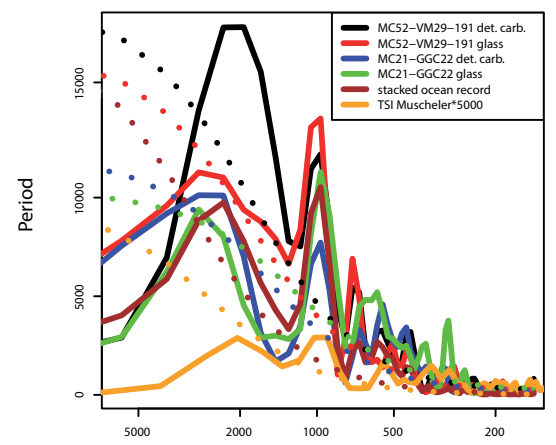

Figure 5. Frequency analysis of model results (70 year mean values because the resolution of the Bond data is 70 years) and IRD data using the PAST software; (a) CTRLv members; (b) LOWv members; (c) HIGHv members; (d) CTRL/LOW/HIGH, sinTSI and fixCLIM experiments; (e) IRD4: cores JR51GC35, MD99-2269, JM961205, MD99-2317 and Past4Future TSI reconstruction; (f) Bond IRD: IRD records presented in Figure 2 of Bond et al. (2001) and TSI reconstruction presented in Bond et al. (2001, Fig. 3b); all Bond (2001) data is from ftp://ftp.ncdc.noaa.gov/pub/data/paleo/contributions_by_author/bond2001/bond2001.txt logarithmic x-axis 
Table 2. Significance Tests (95\%), the T-Test was only performed for the cases with equal variances (negative F-Test); $\mathrm{x}=$ significant; $\mathrm{SST}=$ sea surface temperature; $\mathrm{T} 2 \mathrm{M}=$ air temperature at $2 \mathrm{~m}$; IMF = iceberg melt flux

\begin{tabular}{|c|c|c|c|}
\hline F-TEST $(95 \%)$ & SST & $\mathrm{T} 2 \mathrm{M}$ & IMF \\
\hline CTRLv-LOWv & - & $\mathrm{X}$ & $\mathrm{X}$ \\
\hline CTRLv-HIGHv & $\mathrm{X}$ & $\mathrm{X}$ & - \\
\hline LOWv-HIGHv & $\mathrm{X}$ & $\mathrm{X}$ & - \\
\hline T-TEST (95\%) & SST & $\mathrm{T} 2 \mathrm{M}$ & IMF \\
\hline CTRLv-CTRL & - & $\mathrm{X}$ & $\mathrm{X}$ \\
\hline LOWv-LOW & $X$ & $\mathrm{X}$ & $\mathrm{X}$ \\
\hline HIGHv-HIGH & - & $\mathrm{X}$ & - \\
\hline CTRLv1-v2 & - & $\mathrm{X}$ & $\mathrm{X}$ \\
\hline LOWv1-v2 & $X$ & $\mathrm{X}$ & $X$ \\
\hline HIGHv1-v2 & - & - & - \\
\hline CTRLv1-v3 & $X$ & $X$ & - \\
\hline LOWv1-v3 & - & - & $X$ \\
\hline HIGHv1-v3 & - & - & $X$ \\
\hline CTRLv1-v4 & $X$ & - & - \\
\hline LOWv1-v4 & $X$ & $\mathrm{X}$ & $X$ \\
\hline HIGHv1-v4 & - & - & - \\
\hline CTRLv1-v5 & - & $X$ & $X$ \\
\hline LOWv1-v5 & - & $\mathrm{X}$ & $X$ \\
\hline HIGHv1-v5 & - & - & $\mathrm{X}$ \\
\hline
\end{tabular}

the experiment conducted with fixed climate conditions (fixCLIM) reveals one significant spectral peak at about 1,500 years (Figure $5 \mathrm{~d}$ ), which corresponds to internal ice sheet variability. In the CTRL(v)/ LOW(v)/ HIGH(v) experiments this peak is split into two significant peaks at around 2,000 and 1,000 years due to the climate - ice-sheet interactions.

The high frecquency cycles correspond well to the proxy data (IRD-4, Figure 5e) that is data collected at cores JR51GC35 (Bendle and Rosell-Melé, 2007), MD99-2269 (Moros et al., 2006, Stoner et al., 2007), JM96-1205 (Smith, 2001; Andrews et al., 2010) and MD99-2317 (Jennings et al., 2006, 2011). These cores have been chosen because they cover the Holocene at a reasonable resolution (100 to 25 years). Since the PAST software can handle unevenly spaced data and automatically detrends it, further treatment of the IRD-4 data was not undertaken. Most cores display prominent frequencies at around 400 and 200 years, as well as 1,000 years. Moreover, cores JM961207 and MD99-2317 display frequencies around 2,000 years, which are prominent in all the model results (Figure 5). Using different software (Andrews et al., 2014) analyzed IRD data from cores 
MD99-2322, MD99-2264, and JR51GC35 and also noted significant millennial and multi-century scale periodicities in the detrended time-series.

The data published by Bond et al. (2001), and online available, also displays significant frequencies at 2,000 and 1,000, as well as 500 years (Figure 5). The 1,000 year spectral peak of Bond et al. (2001) coincides with the TSI reconstruction they used in their study (Figure 5f). This frequency is not prominent in the TSI reconstruction applied in the present manuscript, which exhibits significant spectral peaks at 2,000, 400 and 200 years (Figure 5e). The same analysis was performed using a Hanning window function to test the impact of the chosen window function on the occurring frequencies. The difference between the Hanning and the Welch window function is that the Hanning window function has a steeper slope towards the end values, thus incorporates less low frequencies (not shown). The results confirm the peaks seen in Figure 5

An analysis of the timing of minimum TSI values and the occurrence of enhanced IMF revealed a significant time lag of about 60 years when applying a strong $\left(-4 \mathrm{~W} \mathrm{~m}^{-2}\right)$ idealized sinusoidal shaped forcing (sinTSI experiment, Figure 6 6 ). Using this set-up first, we analyzed the occurrence and exact time of the enhanced IMF within 200 years after a minimum TSI event. In 10 out of 14 events the IMF increases strongly that is more than the mean plus two times its standard deviation (Figure 6 a, please note that some arrows overlap). Yet, a similar time lag of about 80 years is found in the CTRLv, HIGHv and LOWv experiments when using periods of strongly decreased TSI forcing as starting time (Figure 6 , c, d). This shows that the cyclic forcing alters the exact timing of the increased IMF, but we cannot confirm that the periods of increased IRD recorded in the ocean sediment cores are related to decreased TSI. Especially because a significant time lag of 80 years between periods of minimum TSI and enhanced IMF is found in CTRLv and LOWv, but not in the HIGHv set-up.

To summarize, we cannot detect a clear impact of the variations in total solar irradiance, independent of the chosen reconstruction (low or high amplitude), nor can we find an evident impact of volcanic eruptions on the timing of the enhanced ice discharge. All model experiments exhibit significant frequencies of 500, 1,000 and 2,000 years of enhanced IMF that correspond well to IRD data. The 2,000 and 1,000 year frequencies resemble internal ice sheet variability ( $\sim 1,500$ years), modulated by ice-sheet - climate interactions. The impact of variations in total solar irradiance on the 310 IMF is seen in the shorter frequencies, 100-400 years, especially when applying the high amplitude forcing.

\subsubsection{The Geographic Origin and Spatial Pattern of Enhanced Iceberg Discharge}

In the following section we will only present the results of the CTRL set-up because, even though the modeled IMF differs significantly between the experiments Table 2, the overall patterns strongly resemble each other. The plots of the other experiments can be found online in the supplementary information. 

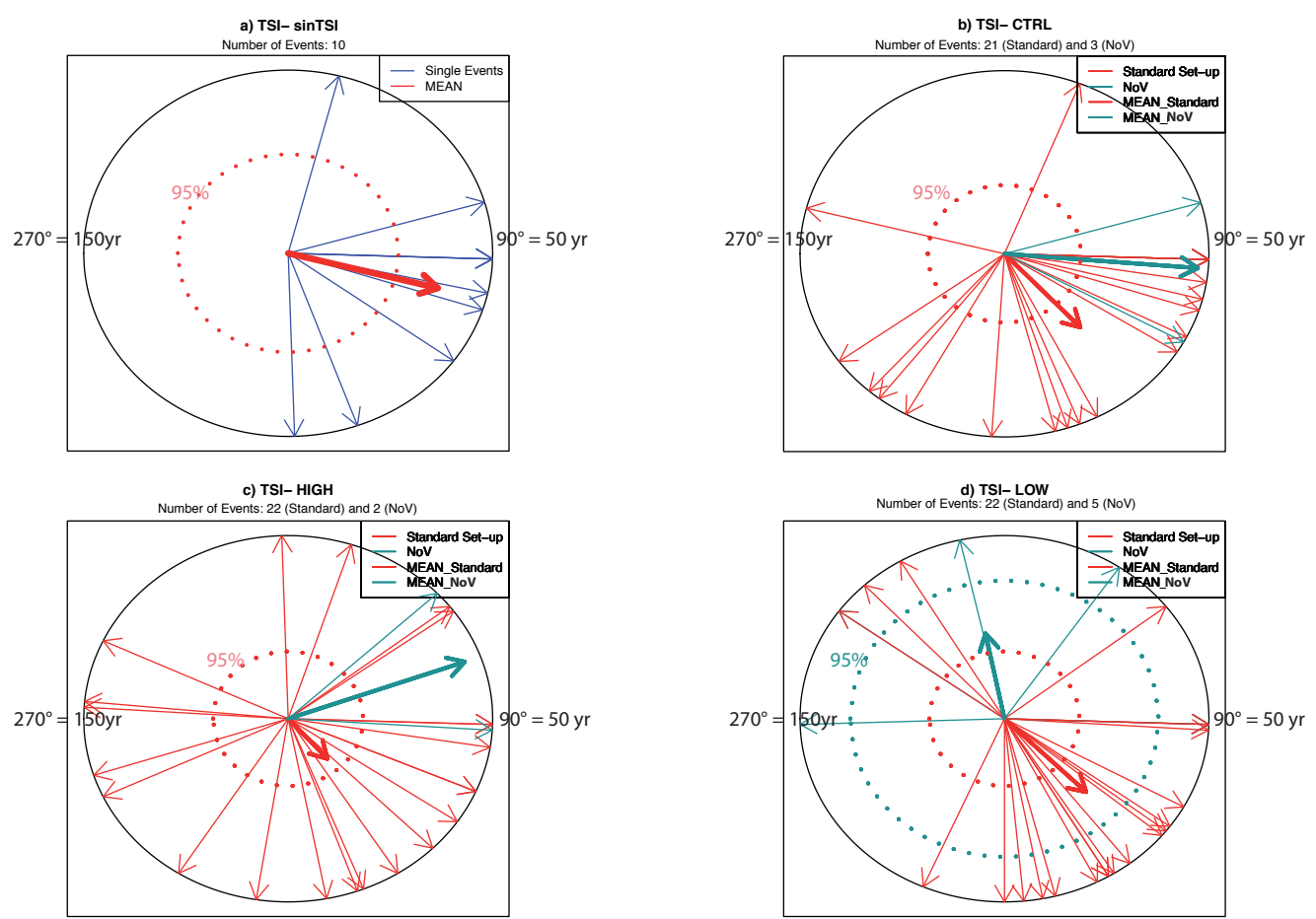

Figure 6. Statistical significance of the phase locking between the applied TSI forcing and the enhanced IMF; the timing of the occurrence of enhanced iceberg melt flux $\left(\operatorname{IMF}(\mathrm{t})>\operatorname{IMF} \_\right.$mean $(\mathrm{t}=1,6000)+2 *$ stdev) relative to defined years of strongly decreased TSI can be displayed as vectors in a unit circle; the period considered following a minimum TSI forcing are 200 years. The bold vectors represent the averaged vector and display a 95\% significant time lag if they exceed the respective dashed circle (color code; note that minimum 4 vectors have to be present to compute a significant averaged direction); (a) is the computed phase locking period of the sinTSI experiment, from year 300 up to 5500 every 400 years were taken as starting year, as described above the following 200 years were; (b) CTRL; (c) LOW; (d) HIGH; for b-d: red corresponds to the ensemble members, darkgreen to the experiment without volcanic forcing; the years of minimum TSI forcing considered are: 650 , 1100, 2580, 3300, 4700, 5580; please note that some arrows overlap. 


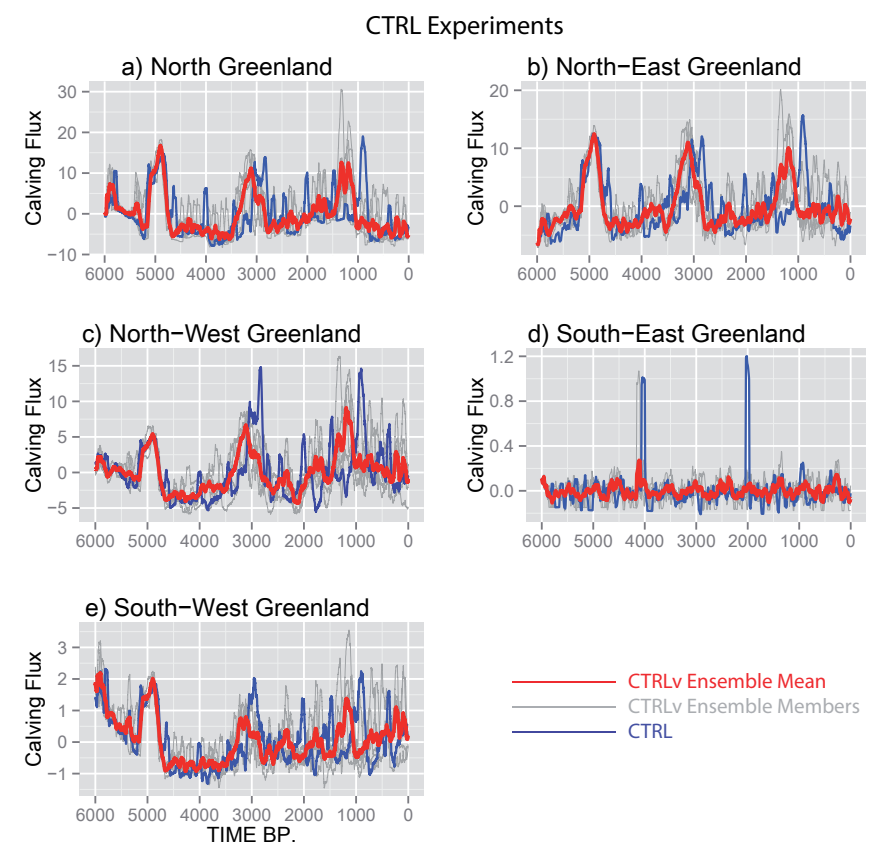

Figure 7. 70 year running mean of the modeled calving flux $\left(\mathrm{m}^{3} \mathrm{~s}^{-1}\right)$ from the calving sites at the respective regions; (a) North Greenland: Lon: $70^{\circ} \mathrm{W}-0^{\circ} \mathrm{E}$, Lat: $80^{\circ}-85^{\circ} \mathrm{N}$; (b) North-East Greenland: Lon: $25^{\circ} \mathrm{W}-$ $0^{\circ}$ E, Lat: $70^{\circ}-80^{\circ} \mathrm{N}$; (c) North-West Greenland: Lon: $70^{\circ}-50^{\circ} \mathrm{W}$, Lat: $70^{\circ}-80^{\circ} \mathrm{N}$; (d) South-East Greenland: Lon: $45^{\circ}-20^{\circ} \mathrm{W}$, Lat: $60^{\circ}-70^{\circ} \mathrm{N}$; (e) South-West Greenland: Lon: $60-45^{\circ} \mathrm{W}$, Lat: $60^{\circ}-70^{\circ} \mathrm{N}$; The thick red line displays the ensemble mean of the 5 ensemble members, the thin grey lines correspond to the individual members and the blue line corresponds to the experiment performed without incorporating volcanic eruptions. Only the CTRL set-up is shown (LOW(v)/HIGH(v) results can be found in the supplementary information).

All the calving sites around Greenland experience periods of enhanced ice discharge over the past 6,000 years, except South - East Greenland (Figure 7). In this region we do not find a recurrent enhanced calving flux, instead the ice discharge of CTRL(v) is relatively constant over time with only one member of CTRLv and the CTRL experiment exhibiting one and two peaks at 4,000 and 2,000 years BP, respectively (Figure 7]d). The calving sites situated at the northern and western site of the Greenland ice sheet (Figure 7, ,b,c,e) display three strong peaks at 5,000, 3,000 and 1,250 years $\mathrm{BP}$ and ?quiet? periods in between. The highest variability is found at the western calving sites of Greenland, where the calving fluxes vary strongly especially over the past 3000 years (Figure 7F,e).

Even though the calving sites South-East of Greenland do not experience periods of increased ice discharge, the composite maps of periods of enhanced iceberg melt flux display intensification all around the ice sheet, especially east and west of it (Figure 8 $)$. In the Arctic and Greenland Sea the increase is directly related to a strongly increased calving flux at the respective calving sites, yet in 


\section{CTRLv-Ensemble Mean}

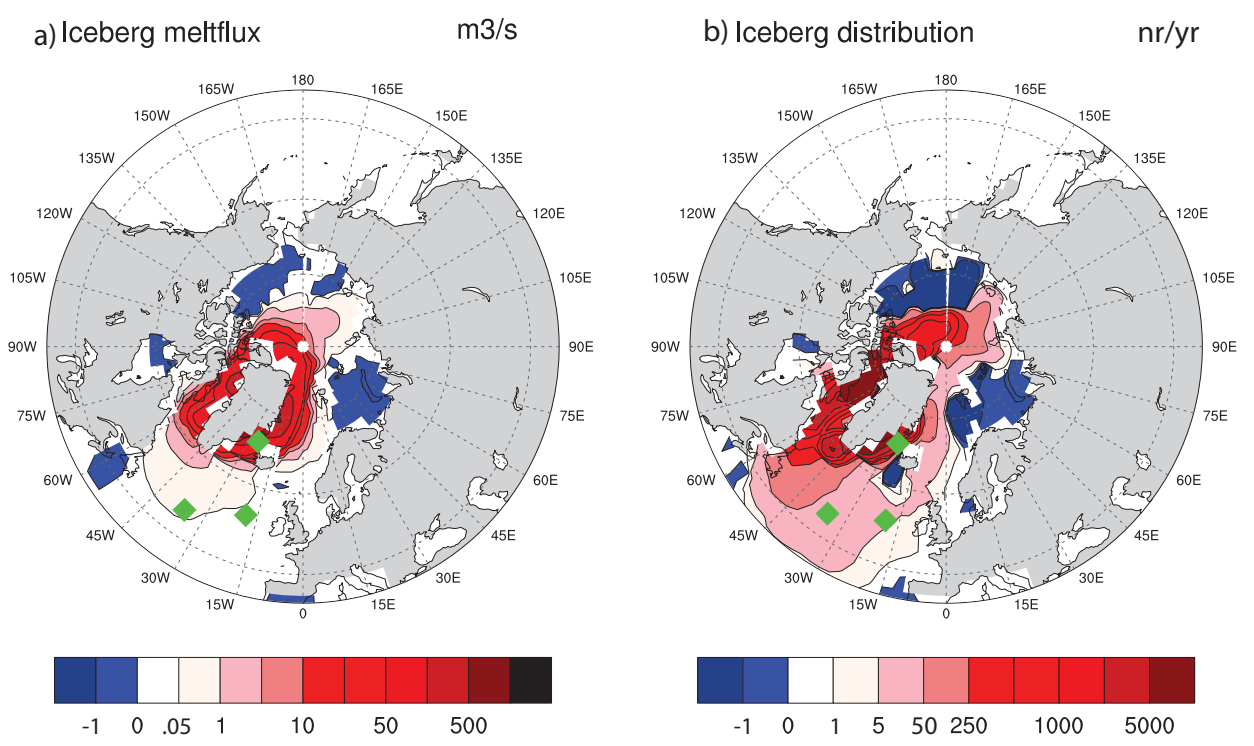

Figure 8. CTRLv-ensemble mean: Composite maps of difference between years of enhanced iceberg melt flux $\left(\mathrm{IMF}(\mathrm{t})>\mathrm{IMF} \_\right.$mean $(\mathrm{t}=1,6000)+2 *$ stdev $)$ and "quiet" periods $(\mathrm{IMF}(\mathrm{t})<\mathrm{IMF}$ mean $(\mathrm{t}=1,6000)+1 *$ stdev $)$; (a) Iceberg Melt Flux $\left(\mathrm{m}^{3} \mathrm{~s}^{-1}\right)$ : (b) number of icebergs moving within one grid cell $\left(\mathrm{nr} \mathrm{yr}^{-1} \mathrm{cell}^{-1}\right)$; nonlinear color scheme! Green rectangles correspond to core locations of Bond et al.(1997,2001). Only the CTRL set-up is shown. LOW(v)/HIGH(v) results can be found in the supplementary information.

the Iceland Sea it is purely due to the transport of the icebergs by the East Greenland current. Also in Baffin Bay the IMF is further strengthened because the East Greenland and the Labrador Current transport the icebergs into this region (Figure 8p). In agreement with Bond et al. (1997), there are more icebergs reaching the core sites of Bond et al. (2001) in the North Atlantic during periods of enhanced ice discharge (Figure $8 \mathrm{p})$, even though there is only a small signal $\left(1 \mathrm{~m}^{3} \mathrm{~s}^{-1}\right)$ in the freshwater flux (Figure 8 $)$.

\section{Discussion}

We used the global climate model $i$ LOVECLIM that includes a fully coupled ice-sheet and iceberg module to perform experiments covering the past 6000 years. This was done in order to investigate whether we can simulate multi centennial to millennial scale variations in IRD that occurred during the Holocene and to analyze the underlying mechanism. The modeled calving and iceberg melt flux clearly display periods of increased ice discharge, but these appear independent of the chosen external forcings (TSI, volcanic eruptions). 
Bond et al. (1997, 2001) claimed variations in incoming TSI responsible for observed variations in IRD thereby causing a lot of debate whether such a small scale forcing could be responsible. Different model studies that investigated the impact of the TSI on climate, which suggested that its effect is further amplified by a stratospheric response (e.g. Haigh, 1994, 1996, 2000; Shindell et al. 2004). The decreased incoming solar radiation causes colder stratospheric conditions due to less ozone formation that consequently alters the atmospheric circulation, resulting in drier conditions in the tropics and a cooling in the mid latitudes. The stratospheric interaction is not taken into account in the model used and might cause an underestimation of the impact of the TSI forcing on climate.

Renssen et al. (2006) proposed that the impact of variations in incoming solar radiance is amplified by the ocean's response. They found a higher probability of colder ocean conditions during times of decreased total solar irradiance due to a weakening of the deep convection in the Nordic Seas using the same atmospheric-ocean-vegetation model as incorporated in $i$ LOVECLIM. We did not find a similar response in deep convection, independent of the chosen TSI forcing. This might be due to the fact that we have included an ice-sheet and an iceberg model that stabilize the modeled climate, which was not incorporated in the study of Renssen et al. (2006).

Recently, various modeling studies focused on the impact of variations in TSI and volcanic eruptions on the Holocene climate and Mignot et al.(2011) showed a stronger model response to volcanic forcing than to variations in incoming TSI. Further, their results suggest general colder temperatures when including volcanic eruptions, which corresponds well to our findings. Miller et al. (2012) displayed that in the used climate model the cooling effect of volcanic eruptions is maintained even for years after the event.

Khider et al. (2014) presented sea surface temperature reconstructions from the western tropical Pacific that exhibit millennial scale variability. Yet, the authors did not find a direct relationship to variations in total solar irradiance or volcanic eruptions and propose that it might be internal variability rather than external forcing factors. This is consistent with our results that the events of increased ice discharge with a periodicity of about 2,000 years occur independently of the use of TSI variations or volcanic eruptions. Instead, the internal ice sheet variability that experiences significant spectral peaks at about 1,500 years is thought to be responsible. Moreover, Wanner et al. (2011) defined six specific cold events covering the Holocene based on global time series of temperature and precipitation/humidity. Their cold events only partly coincide with the occurrence of Bond events, suggesting different mechanisms causing the one and the other.

The spectral analysis on the modeled iceberg melt flux reveals a clear preference towards frequencies at 2,000, 1,000 and 500 years in all the experiments. The experiment with fixed climate conditions that displays internal ice sheet variability revealed just one peak at approximately 1,500 years, indicating that the long-term frequencies are internally driven. Also other modelling studies indicated the occurrence of internal ice sheet variability that appears to depend on the surface temperatures, accumulation rates and sliding parameters (Payne, 1995, Calov et al., 2010). For the ice sheet 
model used, (Ritz et al., 1997) analysed the impact of various model parameters, such as the sliding coefficient or ablation, on the ice volume, ice extent and maximum altitude. The authors found that the ice volume and maximum altitude are strongly affected by the sliding coefficient, whereas the ice extent mainly reacts to the ablation of snow and ice, under present day climate conditions. Implementing the variations in TSI causes the appearance of shorter frequencies in the range of 100-400 years that might correspond to the de Vries and Gleissberg cycles ( $\sim 210$ and $\sim 87$ years, respectively) that were prominent throughout the Holocene (Muscheler et al., 2003: Wagner et al. 2001). The short frequencies are also seen in the IRD data of four ocean sediment cores, as well as peaks at around 1,500, 1,000 and 600 years. These are confirmed by Andrews et al. (2014), who noted frequencies of 1040, 660 and 370 years at cores taken close to the ones used in this manuscript. We did not incorporate core VM28-14 of Bond et al. (2001) in the study because Andrews et al. (2014) noted that its 1,500 year spectral peak might reflect pulses in overflow waters rather than in ice discharge. Obrochta et al. (2012) revised the data of Bond et al. (1997, 2001) and presented prominent peaks at 2,000, 1,000 and 500 years, which support our findings of the model results as well as of the online available data of Bond et al. (2001).

The spatial distribution of icebergs and their freshwater flux during periods of increased ice discharge clearly shows that icebergs are able to spread further into the North Atlantic than during ?quiet? periods. Yet, there are only a few icebergs reaching that far and more importantly, we have not incorporated sediment loads in our iceberg model, thus we cannot predict how much sediments would still be in the icebergs at the time of their arrival at the locations of the ocean sediment cores. It is also important to note that during cold periods, leading to the prolonged existence of fast ice and sikkusaqs, that it can take years for icebergs to exit onto the shelf, hence may already have undergone significant melting and loss of sediment (Dwyer, 1995, Reeh et al., 1999, 2001; Reeh, 2004, Syvitski et al. (1996).

\section{Conclusions}

We simulated the climate of the last 6,000 years using the global climate model $i$ LOVECLIM that incorporates fully coupled ice-sheet and iceberg modules and thus allows for the interactive computation of icebergs. This set-up was used to investigate whether we can model periods of enhanced iceberg melt flux as recorded in ocean sediment cores and to analyze the underlying mechanisms.

We have performed 19 experiments that differ in the applied forcings (variations in total solar irradiance and cooling due to volcanic emissions) and the starting conditions (atmosphere). All the experiments display periods of increased ice discharge from the Greenland ice sheet, independent of the chosen TSI forcing and the implementation of volcanic eruptions. Moreover, the shifted atmospheric starting conditions do not impact the timing of these events that occur at similar model years in all experiments. 
The spectral analysis of the iceberg melt flux displays significant peaks of enhanced values in the range of 2,000, 1,000 and 500 years in all the experiments. Shorter frequencies between 50 and 400 years are especially prominent in the HIGHv set-up, but also appear in the LOWv runs, indicating the role of variations in TSI on that time scales. Moreover, the ice sheet's internal variability displays events of enhanced ice discharge with a significant periodicity of 1500 years. This spectral frequency is modulated to two significant peaks at 2,000 and 1,000 years when actively coupling the climate components to the ice sheet.

Moreover, we applied sinusoidal shaped variations in TSI to investigate its impact on the timing of the events of increased ice discharge. In this experiment we find a significant time lag of 60 years between the minimum TSI and the occurrence of the event. Yet, a common time lag of about 80 years between the minimum incoming solar radiation and the occurrence of increased iceberg melt flux is seen in all the CTRL(v)/HIGH(v) and LOW(v) experiments. We therefore conclude that the variations in TSI do no pace the enhanced iceberg flux at the longer time-scales.

Overall, we provide strong support that the enhanced IRD fluxes found in ocean sediment cores reflect internal ice sheet variability rather than a response to external forcing. This would also explain the different timing of Holocene cold events as defined by Wanner et al. (2011) and Bond events Bond et al. (2001).

Acknowledgements. M. Bügelmayer is supported by NWO through the VIDI/AC ${ }^{2} \mathrm{ME}$ project no 864.09.013. D. M. Roche is supported by NWO through the VIDI/AC ${ }^{2}$ ME project no 864.09.013 and by CNRS-INSU. J.T. Andrews was supported by NSF grand ANS-1107761. The authors wish to thank the Past4Future project for supporting the compilation of the volcanic data set, Catherine Ritz for the use of the GRISLI ice sheet model and Thom Laepple for his advice on the spectral analysis. Institut Pierre Simon Laplace is gratefully acknowledged for hosting the iLOVECLIM model code under the LUDUS framework project (https://forge. ipsl.jussieu.fr/ludus). 


\section{References}

Andersen, C., Koc, N., and Moros, M.: A highly unstable Holocene climate in the subpolar North Atlantic: evidence from diatoms, Quaternary Science Reviews, 23, 2155-2166, doi 10.1016/j.quascirev.2004.08.004 2004.

Andrews, J., Smith, L., Preston, R., Cooper, T., and Jennings, A.: Spatial and temporal patterns of iceberg rafting (IRD) along the East Greenland margin, ca. 68 N, over the last 14 cal. ka, Journal of Quaternary Science, 12, 1-13, doi:10.1002/(SICI)1099-1417(199701/02)12:1<1::AID-JQS288>3.0.CO;2-T, 1997.

Andrews, J. T.: Seeking a Holocene drift ice proxy: non-clay mineral variations from the SW to Ncentral Iceland shelf: trends, regime shifts, and periodicities, Journal of Quaternary Science, 24, 664-676, doi:10.1002/jqs.1257, 2009.

Andrews, J. T., Jennings, A. E., Coleman, G. C., and Eberl, D. D.: Holocene variations in mineral and grain-size composition along the East Greenland glaciated margin $\left(\mathrm{ca} 67^{\circ}-70^{\circ} \mathrm{N}\right)$ : Local versus long-distance sediment transport, Quaternary Science Reviews, 29, 2619-2632, doi:10.1016/j.quascirev.2010.06.001 2010.

Andrews, J. T., Bigg, G. R., and Wilton, D. J.: Holocene ice-rafting and sediment transport from the glaciated margin of east Greenland $\left(67-70^{\circ} \mathrm{N}\right)$ to the $\mathrm{N}$ Iceland shelves: detecting and modelling changing sediment sources, Quaternary Science Reviews, 91, 204-217, doi:10.1016/j.quascirev.2013.08.019, 2014.

Andrews, J. T. et al.: Icebergs and iceberg rafted detritus (IRD) in the North Atlantic: facts and assumptions, OCEANOGRAPHY-WASHINGTON DC-OCEANOGRAPHY SOCIETY-, 13, 100-108, 2000.

Bendle, J. A. and Rosell-Melé, A.: High-resolution alkenone sea surface temperature variability on the North Icelandic Shelf: implications for Nordic Seas palaeoclimatic development during the Holocene, The Holocene, 17, 9-24, doi $10.1177 / 09596836070732692007$.

Berger, A.: Long-term variations of daily insolation and Quaternary climatic changes, Journal of the Atmospheric Sciences, 35, 2362-2367, doi 10.1175/1520-0469(1978)035<2362:LTVODI>2.0.CO;2. 1978.

Bianchi, G. G. and McCave, I. N.: Holocene periodicity in North Atlantic climate and deep-ocean flow south of Iceland, Nature, 397, 515-517, doi:10.1038/17362 1999.

Bigg, G. R., Wadley, M. R., Stevens, D. P., and Johnson, J. A.: Prediction of iceberg trajectories for the North Atlantic and Arctic Oceans, Geophysical research letters, 23, 3587-3590, doi 10.1029/96GL03369 1996.

Bigg, G. R., Wadley, M. R., Stevens, D. P., and Johnson, J. A.: Modelling the dynamics and thermodynamics of icebergs, Cold Regions Science and Technology, 26, 113-135, doi:10.1016/S0165-232X00012-8, 1997.

Bond, G., Showers, W., Cheseby, M., Lotti, R., Almasi, P., Priore, P., Cullen, H., Hajdas, I., Bonani, G., et al.: A pervasive millennial-scale cycle in North Atlantic Holocene and glacial climates, science, 278, 1257-1266, doi $10.1126 /$ science.278.5341.1257, 1997.

Bond, G., Kromer, B., Beer, J., Muscheler, R., Evans, M. N., Showers, W., Hoffmann, S., Lotti-Bond, R., Hajdas, I., and Bonani, G.: Persistent solar influence on North Atlantic climate during the Holocene, Science, 294, 2130-2136, doi 10.1126/science.1065680, 2001.

Bond, G. C., Showers, W., Elliot, M., Evans, M., Lotti, R., Hajdas, I., Bonani, G., and Johnson, S.: The North Atlantic's 1-2 Kyr Climate Rhythm: Relation to Heinrich Events, Dansgaard/Oeschger Cycles and the Little Ice Age, Mechanisms of global climate change at millennial time scales, pp. 35-58, doi $10.1029 /$ GM112p0035 1999. 
Brovkin, V., Ganopolski, A., and Svirezhev, Y.: A continuous climate-vegetation classification for use in climate-biosphere studies, Ecological Modelling, 101, 251-261, doi 10.1016/S0304-3800(97)00049-5. 1997.

Bügelmayer, M., Roche, D., and Renssen, H.: How do icebergs affect the Greenland ice sheet under preindustrial conditions?-a model study with a fully coupled ice-sheet-climate model, The Cryosphere, 9, 821835, doi $10.5194 /$ tc-9-821-2015, 2015.

Calov, R., Greve, R., Abe-Ouchi, A., Bueler, E., Huybrechts, P., Johnson, J. V., Pattyn, F., Pollard, D., Ritz, C., Saito, F., et al.: Results from the Ice-Sheet Model Intercomparison Project-Heinrich Event INtercOmparison (ISMIP HEINO), Journal of Glaciology, 56, 371-383, doi 10.3189/002214310792447789, 2010.

Campin, J.-M. and Goosse, H.: Parameterization of density-driven downsloping flow for a coarse-resolution ocean model in z-coordinate, Tellus A, 51, 412-430, doi:10.1034/j.1600-0870.1999.t01-3-00006.x, 1999.

Crowley, T. J., Zielinski, G., Vinther, B., Udisti, R., Kreutz, K., Cole-Dai, J., and Castellano, E.: Volcanism and the little ice age, PAGES news, 16, 22-23, 2008.

Deleersnijder, E. and Campin, J.-M.: On the computation of the barotropic mode of a free-surface world, Ann. Geophysicae, 13, 675-688, doi 10.1007/s00585-995-0675-x. 1995.

Deleersnijder, E., Beckers, J.-M., Campin, J.-M., El Mohajir, M., Fichefet, T., and Luyten, P.: Some mathematical problems associated with the development and use of marine models, Springer, 1997.

Denton, G. H. and Karlén, W.: Holocene climatic variations-their pattern and possible cause, Quaternary Research, 3, 155-205, doi 10.1016/0033-5894(73)90040-9 1973.

Dowdeswell, J. A., Whittington, R. J., and Hodgkins, R.: The sizes, frequencies, and freeboards of East Greenland icebergs observed using ship radar and sextant, Journal of Geophysical Research: Oceans (1978-2012), 97, 3515-3528, doi 10.1029/91JC02821, 1992.

Dwyer, J. L.: Mapping tide-water glacier dynamics in East Greenland using Landsat data, Journal of Glaciology, 41, 584-595, 1995.

Fichefet, T. and Maqueda, M. M.: Sensitivity of a global sea ice model to the treatment of ice thermodynamics and dynamics, Journal of Geophysical Research: Oceans (1978-2012), 102, 12 609-12 646, doi:10.1029/97JC00480 1997.

Fichefet, T. and Maqueda, M. M.: Modelling the influence of snow accumulation and snow-ice formation on the seasonal cycle of the Antarctic sea-ice cover, Climate Dynamics, 15, 251-268, doi $10.1007 / \mathrm{s} 003820050280$. 1999.

Funder, S., Kjeldsen, K. K., Kjær, K. H., and Cofaigh, C.: The Greenland Ice Sheet during the past 300,000 years: A review, Developments in Quaternary Science, 15, 699-713, doi 10.1016/B978-0-444-534477.00050-7, 2011.

510 Gladstone, R. M., Bigg, G. R., and Nicholls, K. W.: Iceberg trajectory modeling and meltwater injection in the Southern Ocean, Journal of Geophysical Research: Oceans (1978-2012), 106, 19903-19915, doi:10.1029/2000JC000347 2001.

Goosse, H., Brovkin, V., Fichefet, T., Haarsma, R., Huybrechts, P., Jongma, J., Mouchet, A., Selten, F., Barriat, P.-Y., Campin, J.-M., et al.: Description of the Earth system model of intermediate complexity LOVECLIM version 1.2, Geoscientific Model Development, 3, 603-633, doi 10.5194/gmd-3-603-2010, 2010. 
Haigh, J. D.: The role of stratospheric ozone in modulating the solar radiative forcing of climate, Nature, 370, 544-546, doi $10.1038 / 370544 a 0,1994$.

Haigh, J. D.: The impact of solar variability on climate, Science, 272, 981-984, doi $10.1126 /$ science.272.5264.981, 1996.

Haigh, J. D.: Solar variability and climate, Weather, 55, 399-407, doi 10.1002/j.1477-8696.2000.tb06472.x. 2000.

Hammer, Ø., Harper, D., and Ryan, P.: PAST-Palaeontological statistics, www. uv. es/ pardomv/pe/2001_1/past/pastprog/past.pdf, acessado em, 25, 2009, 2001.

Hutter, K.: Theoretical Glaciology: Material Science of Ice and the Mechanics of Glaciers and Ice Sheets, D.Reidel, 1983.

Jennings, A., Hald, M., Smith, M., and Andrews, J.: Freshwater forcing from the Greenland Ice Sheet during the Younger Dryas: evidence from southeastern Greenland shelf cores, Quaternary Science Reviews, 25, 282-298, doi 10.1016/j.quascirev.2005.04.006 2006.

Jennings, A., Andrews, J., and Wilson, L.: Holocene environmental evolution of the SE Greenland Shelf North and South of the Denmark Strait: Irminger and East Greenland current interactions, Quaternary Science Reviews, 30, 980-998, doi 10.1016/j.quascirev.2011.01.016 2011.

Jennings, A. E., Knudsen, K. L., Hald, M., Hansen, C. V., and Andrews, J. T.: A mid-Holocene shift in Arctic sea-ice variability on the East Greenland Shelf, The Holocene, 12, 49-58, doi $10.1191 / 0959683602 \mathrm{hl519rp}$. 2002.

Jongma, J., Renssen, H., and Roche, D.: Simulating Heinrich event 1 with interactive icebergs, Climate Dynamics, 40, 1373-1385, doi 10.1007/s00382-012-1421-1 2013.

Jongma, J. I., Driesschaert, E., Fichefet, T., Goosse, H., and Renssen, H.: The effect of dynamic-thermodynamic icebergs on the Southern Ocean climate in a three-dimensional model, Ocean Modelling, 26, 104-113, doi $10.1016 /$ j.ocemod.2008.09.007 2009.

Jungclaus, J., Lorenz, S., Timmreck, C., Reick, C., Brovkin, V., Six, K., Segschneider, J., Giorgetta, M., Crowley, T., Pongratz, J., et al.: Climate and carbon-cycle variability over the last millennium, Climate of the Past, 6, 723-737, doi 10.5194/cp-6-723-2010 2010.

Khider, D., Jackson, C., and Stott, L.: Assessing millennial-scale variability during the Holocene: A perspective from the western tropical Pacific, Paleoceanography, 29, 143-159, doi 10.1002/2013PA002534 2014.

MacAyeal, D.: Large Scale ice flow over a vicous basal Sediment: Theory and Application to Ice Stream B, Antarctica, Geophys.Research, 94, 4071-4087, doi 10.1029/JB094iB04p04071. 1989.

Mayewski, P. A., Rohling, E. E., Stager, J. C., Karlén, W., Maasch, K. A., Meeker, L. D., Meyerson, E. A., Gasse, F., van Kreveld, S., Holmgren, K., et al.: Holocene climate variability, Quaternary research, 62, 243255, doi $10.1016 /$ j.yqres.2004.07.001 2004.

Mignot, J., Khodri, M., Frankignoul, C., and Servonnat, J.: Volcanic impact on the Atlantic Ocean over the last millennium, Climate of the Past, 7, 1439-1455, doi 10.5194/cp-7-1439-2011 2011.

Miller, G. H., Geirsdóttir, Á., Zhong, Y., Larsen, D. J., Otto-Bliesner, B. L., Holland, M. M., Bailey, D. A., Refsnider, K. A., Lehman, S. J., Southon, J. R., et al.: Abrupt onset of the Little Ice Age triggered by volcanism and sustained by sea-ice/ocean feedbacks, Geophysical Research Letters, 39, doi 10.1029/2011GL050168. 2012. 
Morland, L.: Thermomechanical balances of ice sheet flow, Geo.phys. Astrophy. Fluid Dynam., 29, 237-266, doi: $10.1080 / 030919284082481911984$

Moros, M., Andrews, J. T., Eberl, D. D., and Jansen, E.: Holocene history of drift ice in the northern North Atlantic: Evidence for different spatial and temporal modes, Paleoceanography, 21, doi: $10.1029 / 2005$ PA001214 2006.

Muscheler, R., Beer, J., and Kromer, B.: Long-term climate variations and solar effects, in: Solar Variability as an Input to the Earth's Environment, vol. 535, pp. 305-316, 2003.

Obrochta, S. P., Miyahara, H., Yokoyama, Y., and Crowley, T. J.: A re-examination of evidence for the North Atlantic "1500-year cycle" at Site 609, Quaternary Science Reviews, 55, 23-33, doi:10.1016/j.quascirev.2012.08.008, 2012.

Opsteegh, J., Haarsma, R., Selten, F., and Kattenberg, A.: ECBILT: A dynamic alternative to mixed boundary conditions in ocean models, Tellus A, 50, doi 10.1034/j.1600-0870.1998.t01-1-00007.x. 1998.

Payne, A.: Limit cycles in the basal thermal regime of ice sheets, JOURNAL OF GEOPHYSICAL RESEARCH-ALL SERIES-, 100, 4249-4249, doi:10.1029/94JB02778, 1995.

Peyaud, V., Ritz, C., and Krinner, G.: Modelling the Early Weichselian Eurasian Ice Sheets: role of ice shelves and influence of ice-dammed lakes, Climate of the Past Discussions, 3, 221-247, doi 10.5194/cp-3-375-2007. 2007.

Reeh, N.: Holocene climate and fjord glaciations in Northeast Greenland: implications for IRD deposition in the North Atlantic, Sedimentary Geology, 165, 333-342, doi:10.1016/j.sedgeo.2003.11.023, 2004.

Reeh, N., Mayer, C., Miller, H., Thomsen, H. H., and Weidick, A.: Present and past climate control on fjord glaciations in Greenland: Implications for IRD-deposition in the sea, Geophysical Research Letters, 26, 1039-1042, doi 10.1029/1999GL900065 1999.

Reeh, N., Thomsen, H. H., Higgins, A. K., and Weidick, A.: Sea ice and the stability of north and northeast Greenland floating glaciers, Annals of Glaciology, 33, 474-480, doi 10.3189/172756401781818554 2001.

Reid, E.: Iceberg Distribution on the Grand Banks: Past and Present, 2005.

Renssen, H., Goosse, H., and Muscheler, R.: Coupled climate model simulation of Holocene cooling events: oceanic feedback amplifies solar forcing, Climate of the Past, 2, 79-90, doi 10.5194/cp-2-79-2006 2006.

Ritz, C., Fabre, A., and Letréguilly, A.: Sensitivity of a Greenland ice sheet model to ice flow and ablation parameters: consequences for the evolution through the last climatic cycle, Climate Dynamics, 13, 11-23, doi:10.1007/s003820050149, 1997.

Ritz, C., Rommelaere, V., and Dumas, C.: Modeling the evolution of Antarctic ice sheet over the last 420,000 years: Implications for altitude changes in the Vostok region, Journal of Geophysical Research: Atmospheres (1984-2012), 106, 31 943-31 964, doi:10.1029/2001JD900232, 2001.

Robock, A.: Volcanic eruptions and climate, Reviews of Geophysics, 38, 191-219, doi $10.1029 / 1998 \mathrm{RG} 000054,2000$.

Roche, D., Dumas, C., Bügelmayer, M., Charbit, S., and Ritz, C.: Adding a dynamical cryosphere to iLOVECLIM (version 1.0): coupling with the GRISLI ice-sheet model, Geoscientific Model Development, 7, 13771394, doi:10.5194/gmd-7-1377-2014, 2014. 
Ruddiman, W. F.: Late Quaternary deposition of ice-rafted sand in the subpolar North Atlantic

(lat 40 to $65 \mathrm{~N}$ ), Geological Society of America Bulletin, 88, 1813-1827, doi 10.1130/00167606(1977)88<1813:LQDOIS>2.0.CO;2 1977.

Schulz, M. and Mudelsee, M.: REDFIT: estimating red-noise spectra directly from unevenly spaced paleoclimatic time series, Computers \& Geosciences, 28, 421-426, doi:10.1016/S0098-3004(01)00044-9. 2002.

Shapiro, A., Schmutz, W., Rozanov, E., Schoell, M., Haberreiter, M., Shapiro, A., and Nyeki, S.: A new approach to the long-term reconstruction of the solar irradiance leads to large historical solar forcing, Astronomy \& Astrophysics, 529, A67, doi 10.1051/0004-6361/201016173, 2011.

Shindell, D., Rind, D., Balachandran, N., Lean, J., and Lonergan, P.: Solar cycle variability, ozone, and climate, Science, 284, 305-308, doi 10.1126/science.284.5412.305 1999.

Shindell, D. T., Schmidt, G. A., Mann, M. E., Rind, D., and Waple, A.: Solar forcing of regional climate change during the Maunder Minimum, Science, 294, 2149-2152, doi 10.1126/science.1064363 2001.

Shindell, D. T., Schmidt, G. A., Mann, M. E., and Faluvegi, G.: Dynamic winter climate response to large tropical volcanic eruptions since 1600, Journal of Geophysical Research: Atmospheres (1984-2012), 109, doi $10.1029 / 2003$ JD004151, 2004.

Smith, L.: Holocene environmental reconstruction of the continental shelves adjacent to the Denmark Strait, Ph.D. Dissertation, University of Colorado, Boulder, 2001.

Steinhilber, F., Beer, J., and Fröhlich, C.: Total solar irradiance during the Holocene, Geophysical Research Letters, 36, doi:10.1029/2009GL040142, 2009.

Stoner, J. S., Jennings, A., Kristjánsdóttir, G. B., Dunhill, G., Andrews, J. T., and Hardardóttir, J.: A paleomagnetic approach toward refining Holocene radiocarbon-based chronologies: Paleoceanographic records from the north Iceland (MD99-2269) and east Greenland (MD99-2322) margins, Paleoceanography, 22, doi $10.1029 / 2006$ PA001285 2007.

Syvitski, J., Andrews, J., and Dowdeswell, J.: Sediment deposition in an iceberg-dominated glacimarine environment, East Greenland: basin fill implications, Global and Planetary Change, 12, 251-270, doi:10.1016/0921-8181(95)00023-2 1996.

Ten Brink, N. W. and Weidick, A.: Greenland ice sheet history since the last glaciation, Quaternary Research, 4, 429-440, doi 10.1016/0033-5894(74)90038-6, 1974.

Vinther, B. M., Buchardt, S. L., Clausen, H. B., Dahl-Jensen, D., Johnsen, S. J., Fisher, D., Koerner, R., Raynaud, D., Lipenkov, V., Andersen, K., et al.: Holocene thinning of the Greenland ice sheet, Nature, 461, 385-388, doi $10.1038 /$ nature08355, 2009.

Wagner, G., Beer, J., Masarik, J., Muscheler, R., Kubik, P. W., Mende, W., Laj, C., Raisbeck, G. M., and Yiou, F.: Presence of the solar de Vries cycle ( 205 years) during the last ice age, Geophysical Research Letters, 28, 303-306, 2001.

Walker, M., Berkelhammer, M., Björck, S., Cwynar, L., Fisher, D., Long, A., Lowe, J., Newnham, R., Rasmussen, S. O., and Weiss, H.: Formal subdivision of the Holocene Series/Epoch: a Discussion Paper by a Working Group of INTIMATE (Integration of ice-core, marine and terrestrial records) and the Subcommission on Quaternary Stratigraphy (International Commission on Stratigraphy), Journal of Quaternary Science, 27, 649-659, 2012. 
Wanner, H., Beer, J., Buetikofer, J., Crowley, T. J., Cubasch, U., Flueckiger, J., Goosse, H., Grosjean, M., Joos, F., Kaplan, J. O., et al.: Mid-to Late Holocene climate change: an overview, Quaternary Science Reviews, 635 27, 1791-1828, doi 10.1016/j.quascirev.2008.06.013 2008.

Wanner, H., Solomina, O., Grosjean, M., Ritz, S. P., and Jetel, M.: Structure and origin of Holocene cold events, Quaternary Science Reviews, 30, 3109-3123, doi:10.1016/j.quascirev.2011.07.010, 2011.

Wanner, H., Mercolli, L., Grosjean, M., and Ritz, S.: Holocene climate variability and change; a data-based review, Journal of the Geological Society, 172, 254-263, doi:10.1144/jgs2013-101 2015.

640 Wiersma, A. P. and Jongma, J. I.: A role for icebergs in the 8.2 ka climate event, Climate dynamics, 35, 535-549, doi $10.1007 / \mathrm{s} 00382-009-0645-12010$. 